\title{
A SURVEY OF EXOCENTRIC COMPOUNDS IN THREE KWA LANGUAGES: AKAN, EWE AND GA
}

\author{
Clement Kwamina Insaidoo Appah
}

\begin{abstract}
Whereas the existence of exocentric compounds is taken for granted in the literature on compounding, there are just a few studies devoted to the nature and types of exocentric compounds cross-linguistically and in African languages in particular, leaving exocentricity in African languages severely under-researched. This paper seeks to contribute to knowledge on exocentricity by exploring the range of exocentric compounds in three Kwa languages - Akan, Ewe and Ga - in the context of the typology of exocentric compounds proposed by Bauer (2008a, 2010) who posited five types - bahuvrihi, exocentric synthetic, exocentric co-compounds, transpositional exocentric and metaphorical compounds. Appah (2016b, 2017b) argued that three of the five types (bahuvrihi, exocentric synthetic and transpositional exocentric compounds) with various subtypes occur in Akan. The equivalent of Bauer's metaphorical compounds was subsumed under bahuvrihi compounds, while the absence of exocentric co-compounds was argued to be an areal feature, given the observation that co-compounds are rare in Africa (Wälchli 2005). This paper shows that apart from exocentric co-compounds, the rest are found in the languages under discussion to varying extents. All three languages have metaphorical and location bahuvrihi compounds, but the status of the possessor bahuvrihi type is not certain, except in Akan. Ewe has agentive exocentric synthetic compounds, but not the action and patient types, whilst Ga has none. Again, only Ga does not have transpositional exocentric compounds. Finally, it is observed that all the compounds are nouns, notwithstanding the syntactic category of the constituents. This is another potential areal feature.
\end{abstract}

Keywords: Akan, Areal feature/Typology, Bahuvrihi, Ewe, Exocentric compounds, Ga, Synthetic 


\section{Introduction}

A principal distinction in the classification of compounds is that between endocentric compounds like door bell, which is a hyponym of its head constituent (door bell is a type of bell) and exocentric compounds, like killjoy, which is not a hyponym of either constituent (Bloomfield 1933, Marchand 1969). The received wisdom is that endocentric compounds are very common in the languages of the world. Consequently, they have received a lot of research attention. The same cannot be said about exocentric compounds which are said to be relatively rare (Bauer 2010, Dressler 2006, Guevara and Scalise 2009, Scalise and Guevara 2006). The purpose of this paper, therefore, is to contribute to an area of research on compounding that is relatively underserved crosslinguistically and in African languages in particular by identify and discussing exocentric compounds in three closely related and neighbouring Kwa languages Akan, Ewe and $\mathrm{Ga}$ - within the framework of the categories and terminology proposed by Bauer (2008a:51-52) for discussing exocentric compounds.

Data from the three languages are tested with the view to establishing which of the posited types of exocentric compounds occur in the languages. Contra previous studies (Appah 2016b, 2017b) that suggested that Akan had only three of the five types posited by Bauer, the present study shows that Akan has four (bahuvrihi, exocentric synthetic, transpositional exocentric and metaphorical compounds) which Ewe and Ga also exhibit to varying extents.

The section on Akan is based on studies on Akan compounding in its various dimensions and manifestations (cf. Appah 2013, 2015, 2016a, c, 2017a, b, Appah, Duah and Kambon 2017, Appah 2019), based on data drawn from different sources, including an elementary school reader on fishing (Otoo 1946), the Akan translation of the Universal Declaration on Human Rights and an Akan translation of Plato's apology of Socrates. The Ewe and $\mathrm{Ga}$ data were elicited mainly from native-speaker graduate linguistics students as well as faculty at the University of Ghana. Some Ewe data were also collected or confirmed from three studies (Agbadah 2017, Ameka 1991, Ofori 2002) and I crosschecked the elicited data with other non-linguist speakers of Ewe and $\mathrm{Ga}$. Any elicited construct whose existence could not be confirmed at all by any of my consultants were left out of the dataset. However, where there was mixed judgement on some data, I kept the data and explained it in the paper, as the discussion in section 4 will show. Starting with what had been found in Akan (Appah 2016b, 2017b), the approach was to find out if the same or similar construction types would be found in Ewe and $\mathrm{Ga}$ as well. For example, for the section on bahuvrihi compounds (section 4.1), the idea was to find out how the following meanings, which are attested in Akan as bahuvrihi compounds, are expressed in Ewe and Ga: one who possesses $\mathrm{X}$ feature/property/item, one who does $X$, a place where $X$ happens, or a place where $X$ is 
located. Here, X stands for the compositional meaning of the compound and there is no constituent which directly codes the highlighted meaning or, where present, the constituent representing the highlighted portion is interpreted metaphorically or metonymically.

In the rest of the paper, there is a general discussion of exocentricity in the context of compounding in section 2 and a presentation of Bauer's typology of exocentric compounds in section 3, exemplifying the types posited and recent suggested modifications in Appah (2016b, 2017b). Section 4 deals with the types of exocentric compounds in the three languages, and the paper is concluded in section 5, where I show the pattern that emerges from the study in terms of the types of exocentric compounds found in the three Kwa languages as well as the current structure of the typology, based on Bauer's proposal and the suggested subtypes. Thus, one contribution of this paper to research on compounding is the indication that exocentric compounds may not be as rare in the languages of the world as previous studies have suggested. However, this study has to be properly construed as a preliminary survey that provides direction for further study of the phenomenon of exocentricity in the three languages, especially the portions on Ewe and Ga.

\section{Exocentricity}

The notion of exocentricity has been characterized in various ways (Andreou and Ralli 2015, Bauer 2008a, 2010, 2017, Bloomfield 1933, Plag 2003, Ralli and Andreou 2012, Scalise and Guevara 2006) and claims have been made about whether or not it is an exclusive feature of compounds (Bauer 2016, Bisetto and Scalise 2007, Ralli 2013). For example, in what they call the exocentricity principle, Bisetto and Scalise (2007:363) claim that exocentricity is an exclusive feature of compounds. However, as will become clear from the discussion below, this view is not shared by many, especially researchers with Cognitive Linguistics persuasion.

In the literature on compounding, various types of heads are distinguished semantic head, formal head, syntactic head, morphological head, etc., which may not necessarily pick out the same element in a compound (cf. Andreou 2014, Di Sciullo and Williams 1987, Katamba and Stonham 2006, Scalise 1988, Scalise and Guevara 2006, Scalise and Fábregas 2010, Selkirk 1982). A prominent distinction, and one that is relevant to contemporary studies of exocentricity, is that between semantic head and formal head. The semantic head is the element that shares its lexical conceptual information with the whole compound, so that the compound will be a hyponym of the semantic head (Scalise and Guevara 2006:190). The formal head is characterized as the constituent that shares its lexical category and subcategorization frame with the whole 
compound, so that the compound has the same distributional properties as its formal head (Scalise and Guevara 2006:190). ${ }^{1}$

Building on the distinction between formal head and semantic head there is growing consensus in recent literature on a concomitant distinction between semantic exocentricity and formal exocentricity (cf. Andreou and Ralli 2015, Appah 2016b, 2017b, Bauer 2008a, 2010, 2016, Plag 2003, Ralli and Andreou 2012, Ralli 2013, Scalise and Guevara 2006). A semantically exocentric compound is one which lacks a semantic head, as in the case of English killjoy, which is not a hyponym of either kill or joy. A formally exocentric compound, on the other hand, is one which lacks a formal head or a crucial formal feature such as the syntactic category. An example found in Marchand (1969) is the noun blackout, which is formed out of a verb and a preposition/adverb/particle. Another example is the Akan verb-verb nominal compound gye-di 'faith/belief' [lit. receive-eat], which is a noun formed from two verbs, so that the syntactic category cannot be said to emanate from the constituents which are both verbs (Appah 2015, 2017a).

Exocentric compounds are generally considered to be marked relative to endocentric compounds because, according to Dressler (2006), not only are they rare in the languages of the world, but they are also limited in the classes of words that they form. For example, it will become clear that all the exocentric compounds in the three Kwa languages under discussion are nouns, notwithstanding the syntactic category of the constituents. Again, the syntactic category of the constituents of exocentric compounds also tend to be quite restricted. In fact, there are scholars who, based on how exocentric compounds are interpreted, have sought to argue that there is no need to posit a separate class of compounds called exocentric compounds (see Bauer 2016, Benczes 2005a, b, 2006, Benczes 2015, Booij 2002). Booij, for example, takes this position when he argues that "what have been called exocentric compounds or bahuvrihi compounds are a specific semantic category of endocentric compounds based on metonymy: a part of an entity is used to refer to the whole entity. This is what is at stake with the classical English example of a bahuvrihi compound redskin" (Booij 2002:143). Bauer (2016:466) also suggests the term non-hyponymic compounds as an alternative to exocentric compounds. However, the problem of formal exocentricity still remains unresolved with this suggestion. I believe that we have to distinguish

\footnotetext{
${ }^{1}$ Dressler (2006:32-33) illustrates the different heads, arguing that in pickpocket, there is no semantic head because the referent of the compound is not named in the compound itself. Pick is the syntactic head because it is that which selects pocket as its internal argument. Pocket is the morphological head because, when the compound is pluralized, the plural marker attaches to pocket, as in pickpocket-s and not pick-s-pocket. However, as discussed in the literature (Bauer 2010, Booij 2007), the problem with Dressler's position on morphological head is that the position of the inflectional element in a word may be a default in the language and may not necessarily identify a morphological head.
} 
between the fact of the existence of a class of compounds which are not hyponyms of their constituents and how the members of that class are interpreted. In my view, these two issues tend to be lumped, where indeed, the focus is on the interpretation of exocentric compounds, and so what is taken into account is semantic exocentricity, leaving out the question of how to deal with formally exocentric compounds.

Claims about the restrictedness of exocentric compounds seem to find support in the fact that there aren't many studies of exocentric compounds in the languages of the world. Notable exceptions are found for English (Bauer 2008b), Modern Greek (Andreou and Ralli 2015, Ralli and Andreou 2012, Ralli 2013) and Akan (Appah 2017a, b, Appah, Duah and Kambon 2017). The studies on Akan build on what, in my view, is clearly the only veritable cross-linguistic study of the typology of exocentric compounds, that is Bauer (2008a, 2010), which is presented in section 3. The other known attempt at a cross-linguistic study of exocentric compounds (Scalise and Guevara 2006) considers whether the three macro-types of compounds - attributive, subordinate and coordinate - have exocentric versions. Scalise and Bisetto (Bisetto and Scalise 2005, Scalise and Bisetto 2009) also deal with the syntactic category of the input and output as well as their structural types and combinations. However, their studies are somewhat limited in terms of the typological profile and geographical spread of the languages covered, as their studies cover seventeen languages of which only two (Chinese and Korean) are spoken outside of Europe (cf. Scalise and Guevara 2006:204, n. 3).

\section{Bauer's typology of exocentric compounds and subsequent modifications}

Working with data drawn from about fifty languages of varied genetic affiliation, Bauer (2008a, 2010) breaks new ground in the study of exocentric compounds, providing both a typology and, as he puts it, "a (provisional) terminology for discussing them" (Bauer 2008a:51-52). This section presents Bauer's (2008a, 2010) typology of exocentric compounds as well as suggested elaborations based on data from Bauer's work and others drawn from Akan (Appah 2016b, 2017b). The approach to the discussion here is largely descriptive, as a detailed critical assessment of Bauer's typology and the basis of the proposed modification is beyond the immediate goals of the present paper. For that, the interested reader may consult Appah (2016b, 2017b).

Bauer (2008a, 2010) characterizes an exocentric compound as one that fails the hyponymy test because it fails to display a head element, functions as a member of a word class that is not the word class of the head element or can have a head element of the correct word class but with the wrong denotation. From this premise, Bauer provides a typology of exocentric compounds based on data from the fifty typologically diverse languages. The types he posits are bahuvrihi, exocentric synthetic, 
transpositional exocentric, exocentric co-compounds and metaphorical compounds. The various types are defined and exemplified below, together with subtypes proposed by Appah (2016b, 2017b).

Traditionally, a synthetic compound refers to an endocentric construction, like English truck driver $\left[[\text { truck }]_{\mathrm{N}}\left[\left[\text { drive }_{\mathrm{V}}-\mathrm{er}\right]_{\mathrm{N}}\right]_{\mathrm{N}}\right.$, in which one constituent is derived. Here the affix -er on the right-hand constituent corresponds to the external argument of the underlying verb - drive. The exocentric synthetic compound, according to Bauer (2008a:61) is the kind which, unlike the endocentric synthetic compound, has no morpheme like English -er, which corresponds to the external argument of the verb. Rather, as exemplified by French gratte-ciel 'skyscraper' [lit. scratch-sky], the head verb and its internal argument form a noun that denotes the entity that performs the action. That is, only the verb and its internal argument are present, but the compound as a whole refers to the external argument - that which scratches the sky. Appah (2017b) suggests, based on data from Akan, that the exocentric synthetic compounds can be grouped into two subtypes - action (nominal) and participant exocentric synthetic compounds. The participant exocentric synthetic compounds can also have subtypes, like agentive, patient and location. These will be discussed further and exemplified in section 4.

A Bahuvrihi compound is the type that "expresses some salient facet of the denotatum" (Bauer 2008a:56) but is not a hyponym of either constituent. An example is Sanskrit bahu-vrihi 'much rice' which refers to 'one who/which has much rice', although none of the constituents names a person. Based on Bauer's data, Appah (2017b) suggested two types of bahuvrihi compounds which are named after the missing meaning component, considering the compositional meaning of the compound. The first is the possessive type which is the commonest (cf. Andreou and Ralli 2015, Benczes 2015, Ralli and Andreou 2012, Ralli 2013) and its meaning may be schematised as "entity which possesses X", where X stands for the compositional meaning of the compound. Thus, what is missing in the compound itself is the possessor or the one who has/owns the referent of the compositional meaning of the compound. This is what bahu-vrihi exemplifies. The second is the causer type which refers to the element that causes the compositional meaning of the compound. It is exemplified by the compound red eye 'cheap whisky/overnight flight' which does not denote an entity that possesses red eye (cf. Bauer 2010:167). Rather, the referent of the compound cheap whisky or overnight flight - causes the red eye. So, the missing meaning component is the causer of the compositional meaning of the compound.

Subsequently, ${ }^{2}$ Appah (2016b) posited a non-possessive type of bahuvrihi compounds with a property subtype which is made up of compounds that refer to some

\footnotetext{
${ }^{2}$ It is worth noting that Appah (2017b) predates Appah (2016b), but the latter appeared before the former.
} 
property of the referent of the compositional meaning of the compound, including constructs that fit Bauer's description of metaphorical compounds as provided below. Again, it was argued that the locative subtype under the participant exocentric synthetic compound may be properly classified as a subtype of non-possessive type of bahuvrihi compound. Thus, the non-possessive bahuvrihi compounds had three subtypes and the metaphorical compound class as a separate subtype of exocentric compound was done away with, at least for Akan.

A transpositional exocentric compound is the type of compound whose word class is not overt in that the compound does not share the word class of either constituent (Bauer 2010:171). The meaning of the transpositional exocentric compound may be transparent. However, it is formally exocentric because it "functions as a member of an unexpected word-class" (Bauer 2008a:64). An example is Swahili ujauzito 'pregnancy' [lit. come-heavy], which is a noun formed from a verb and an adjective (Bauer 2008a:65).

An exocentric co-compound is the type of coordinate compound in which two constituents enjoy parity in terms of their importance in the compound "but the compound is not a hyponym of either element" (Bauer 2008a:63). An example is the Chantyal (Sino-Tibetan: Tibeto-Burman) compound nhe thara 'dairy products' [lit. 'milk buttermilk'] (Bauer 2008a, 2010, Wälchli 2005). This class is noted to be rare in African Languages (Wälchli 2005).

Finally, a metaphorical exocentric compound, according to Bauer (2010), arises where a compound fails the hyponymy test because the head element or the compound as a whole has a metaphorical interpretation (e.g., dust bowl 'an area with no vegetation' or catlick 'quick wash') or a metonymic interpretation (e.g., phone neck 'pain in the neck caused by using a phone', or bear skin 'hat won by certain soldiers'). It is worth pointing out that Bauer is quite sceptical about whether the notion of exocentricity is appropriate for the constructs in this group. One reason is that sometimes whether a compound would be deemed exocentric or not is a matter of interpretation (Bauer 2016, Fabb 1998). Also, I find that sometimes there is very little to choose between the interpretation of some compounds classified as metaphorical and others classified as bahuvrihi. For example, it may be difficult to tell what the real distinction is between red eye (bahuvrihi compound) and phone neck (metaphorical compound) as presented in Bauer (2008a, 2010). That is why, in Appah (2017b), the constructs that fit Bauer's description of metaphorical compounds were treated as a subtype of property bahuvrihi compounds whose members get interpreted by figures of speech, including metaphor and metonymy.

Thus, the state of the research on the typology of exocentric compounds as presented in Appah (2016b), based on Bauer's framework (Bauer 2008a, 2010) is as shown in (1). 
Typology of exocentric compounds (Appah 2016b:112)

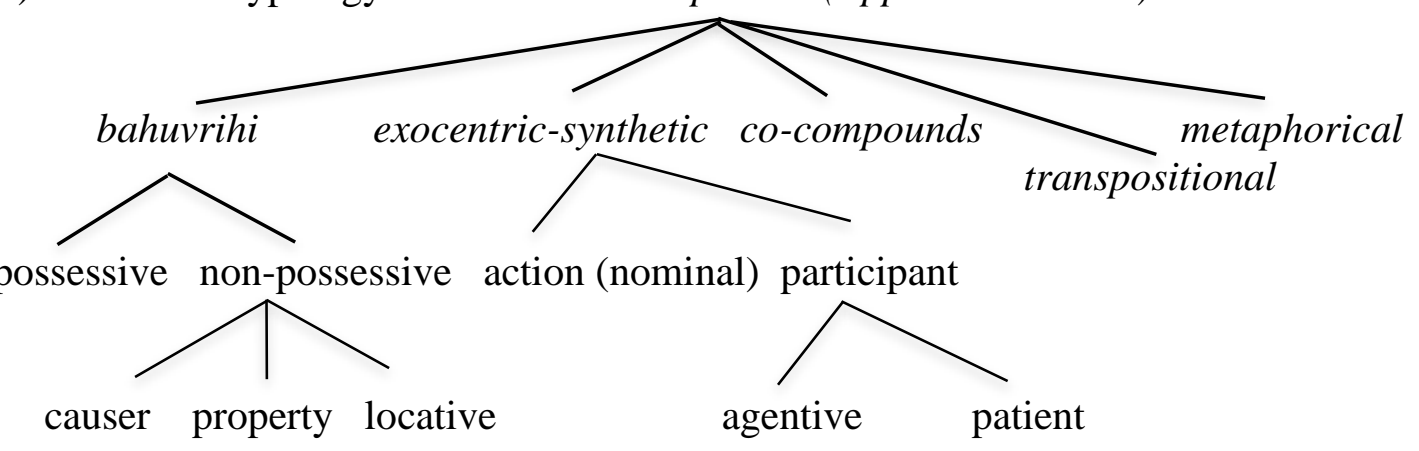

The discussion in the next section will lead to another slight modification of the typology of exocentric compounds, where we will drop "non-possessive" as a cover term for all other types of bahuvrihi compounds apart from the possessive type which we will refer to as the possessor type. The current property type too will be reclassified as metaphorical compounds, reverting to Bauer's recognition of a separate class of metaphorical compounds.

\section{Exocentric compounds in the three Kwa Languages}

In this section, I present the types of exocentric compounds in the three Kwa languages, based on the framework established in section 3. I begin each subsection with what has been found in Akan and then proceed to show whether the type in question is found in Ewe and $\mathrm{Ga}$ as well. Where possible, if a particular type that occurs in Akan is not found in either of the two languages, I indicate how the language in question expresses the meaning that is encoded in the corresponding Akan exocentric compound. Thus, it is shown that for some of the compounds, the two languages have forms that overtly code the meaning that is missing in the corresponding Akan exocentric compounds.

\subsection{Bahuvrihi compounds}

As noted above, bahuvrihi compound is the type in which a crucial semantic property needed for the interpretation of the compound is outside of the compound. The two principal types identified in Appah (2016b) are the possessive and non-possessive bahuvrihi compounds. In this section, the former is referred to as the possessor type and "non-possessive" as a cover term for the other types of bahuvrihi compounds is dropped. The property type is done away with and its members put in the class of metaphorical compounds. Thus, the subtype of the bahuvrihi compounds discussed below are the possessor and the locative types. 


\subsubsection{Possessor bahuvrihi compounds}

The possessor bahuvrihi compound, refers to the possessor of the compositional meaning of the compound, although there is no constituent that directly refers to the possessor (where possessor interprets as 'entity with', 'entity which has' or 'entity characterised by'). What makes this type of compound exocentric is the absence of an overt unit that carries the possessor meaning. For example, the idiomatic meaning of Akan k̇̀ntséńtsén 'person with a long neck' (Table 1) is more than the sum of the meanings of the parts, $\boldsymbol{k} \boldsymbol{x} \boldsymbol{n}$ ' 'neck' and tséntsén 'long', whose literal meaning is 'long neck'. So, there is no marker for the 'possessor of' or 'person with' meaning, although the compound refers to one who possesses a long neck. The same can be said for all the examples in Table 1 because the possessor of the compositional meaning of the compound is not overtly expressed in the construction.

Table 1: Possessor bahuvrihi compounds in Akan

\begin{tabular}{|c|c|c|c|c|}
\hline Compound & Constituents & Element gloss & Meaning & Pattern \\
\hline ìtsìrkèsé & ìtsíŕ-kèsé & head-big & person with a big head & $\mathrm{N}-\mathrm{A}$ \\
\hline ìtsìrkèlèǹkélè & ìtsír-kèlèǹkélè & head-big & person with a big head & $\mathrm{N}-\mathrm{A}$ \\
\hline kòǹ̀tséńtséń & kóń-tséńtséń & neck-long & person with a long neck & $\mathrm{N}-\mathrm{A}$ \\
\hline hwèǹkèséé & hwéné-kèséé & nose-big & person with a big nose & $\mathrm{N}-\mathrm{A}$ \\
\hline náńkòǹhwéáá & náńkóń-hwéáá & ankle-thin & person with thin legs & $\mathrm{N}-\mathrm{A}$ \\
\hline ànàǹtá & 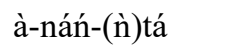 & PL-leg-twin & person with knock knees/valgum & $\mathrm{N}-\mathrm{N}$ \\
\hline àsò kèté & àsó-kغ̀té & ear-mat & person with big ears & $\mathrm{N}-\mathrm{N}$ \\
\hline tsìrpá & tsíŕ-pá & head-bald & bald head person & $\mathrm{N}-\mathrm{V}$ \\
\hline
\end{tabular}

In terms of the constituents and the relation obtaining between them, within the compound, we see that the Akan possessor bahuvrihi compounds are made up of nouns naming body parts such as ìtsír 'head', àsó 'ear', àkòmá 'heart', and kóń 'neck' which have certain properties expressed mostly by adjectives which tend to be either dimension adjectives, like kèsé 'big', and tséńtsén 'long' or physical property adjectives like hyè̀̀ 'hot' (Dixon 2004, Osam 1999). The property may also be expressed by a noun and, in one case, by a verb pá 'to skim, remove, wipe off'. Clearly, the Akan examples in Table 1 are not exactly like the Sanskrit bahu-vrihi. Rather, the compound refers to the owner of the body part about which some property is predicated. That is why the possessor label has to be interpreted, on occasion, as 'owner', 'one having', 'one with', etc.

Ewe seems to have the possessor types of bahuvrihi compounds, as the data in Table 2 show. However, some consultants indicated that they would normally have a form to' 'person' which refers to the owner of the compositional meaning of the base 
that $\boldsymbol{t}$ ' attaches to. For example, one consultant indicated that, in place of the compounds in Table 2, rows $3 \& 4$, he would have the forms with tó (as in nútsótsótó 'gossip' and tàgbófáfát’́ 'dumb person'). It seems to me, however, that the form tó is not always needed since the same consultant acknowledges that compounds like fòdòg $\tilde{\boldsymbol{a}}$ 'person with a big belly' may not need the form tó because the intended meaning may be conveyed without $t$ '́.

Table 2. Possessor bahuvrihi compounds in Ewe

\begin{tabular}{|c|c|c|c|c|}
\hline Compound & Element & Element Gloss & Meaning & Pattern \\
\hline fòdògã́ & fódó-gấ & belly-big & person with big belly & N-A \\
\hline àfòtílenge & àfòtí-lēnge & tiny/slim-leg & person with thin legs & $\mathrm{N}-\mathrm{A}$ \\
\hline nútsótsóē & nú-tsótsóē & mouth-sharp & one who insults/gossip & $\mathrm{N}-\mathrm{A}$ \\
\hline tàgbófáfá & tàgbó-fáfá & head-cold & blockhead/dumb person & $\mathrm{N}-\mathrm{A}$ \\
\hline tàgbólō & tà-gbólō & head-empty & empty-headed person & $\mathrm{N}-\mathrm{A}$ \\
\hline tàgã & tà-gã & head-big & person with a big nose & $\mathrm{N}-\mathrm{A}$ \\
\hline yòtsílókpō & jòtsí-lókpō & nose-bulky & person with a bulky nose & $\mathrm{N}-\mathrm{A}$ \\
\hline jukúgã & yukú-gã̃ & eye-big & person with big eyes & $\mathrm{N}-\mathrm{A}$ \\
\hline kpebaye & kpe-baye & hip-flat & person with flat hips & $\mathrm{N}-\mathrm{A}$ \\
\hline
\end{tabular}

Some Ga consultants gave the constructs in Table 3 as the Ga equivalents of some of the Akan possessor bahuvrihi compounds in Table 1 above. However, like Ewe, the status of the possessor bahuvrihi compounds in Ga seems to be in doubt because a number of Ga scholars (personal communication) suggest that there are no such compounds since, for them, in all instances of such constructions, there is a suffix $\boldsymbol{t} \boldsymbol{s} \dot{\boldsymbol{\varepsilon}}$ (sometimes, l⿳亠丷厂巾) that carries the meaning 'possessor/owner of' or 'person characterised by'.

Table 3. Possessor bahuvrihi compounds in $\mathrm{Ga}$

\begin{tabular}{llllc}
\hline \multicolumn{1}{c}{ Compound } & Constituents & Element Gloss & Meaning & Pattern \\
\hline yítsò àgbò & yítsó-àgbò & head-big & person with a big head & N-A \\
gúgòǹ àgbò & gúgóń-àgbò & nose-big & person with a big nose & N-A \\
mùsù àgbò & mùsù-àgbò & belly-big & person with big belly & N-A \\
nànè légélégé & nànè-légélégé & leg-slender & person with thin legs & N-A \\
tòí pàpà & tòí-pàpà & ear-fan & one whose ears are like fans & N-N \\
nààbú àtó & nààbù-àtó & mouth-ladle & one whose mouth is like a ladle & N-N \\
nààtsòtsùròj & nààbú-tsòtsùròj & mouth-heavy/hanging & One with big hanging mouth & N-A/V \\
\hline
\end{tabular}

I sought to find out the possibility of using these Ga constructs without the marker $\boldsymbol{t} \mathbf{s} \grave{\varepsilon}$ and noted that, like Ewe, the compounds without the marker $\boldsymbol{t} \mathbf{s} \grave{\varepsilon}$ are also acceptable (see the constructions in (2)), except that the consultants thought they would use them only in pejorative contexts as unique identifiers for the referents. 
(2) Possessor bahuvrihi compounds illustrated in Ga.
a. yítsò-àgbò nì bà-à head big FOC come-PROG
'It is big head (person with a big head) who is coming.'
b. Yítsò-àgbó lé nì bà-à
head big the FOC come-PROG
'there comes the big head (person with a big head)'
c. Mì-nà gúgòǹ-àgbò yè Legon
1SG-see.PAST nose-big LOC Legon
'I saw big nose (person with a big nose) in Legon'

The views expressed about the context in which the Ga possessor bahuvrihi compound may be used accords well with some Ewe speakers' assessment of the possibility of using the possessor bahuvrihi without the form $t$ 's which marks possessor. An Ewe speaker points out that some family names have the structure of the possessor bahuvrihi compounds. An example is the family name Tàg $\tilde{a}$ 'big head', which serves as a unique identifier.

If the constructions without the overt markers are indeed acceptable, as the consultants claim, then it suggests that in both Ewe and Ga the possessor meaning can be conveyed without an affix that carries the meaning 'possessor'/'owner', as the examples in Table 2 and Table 3 respectively show. However, there is a clear preference for the more transparent means of expression with the possessor/owner meaning overtly marked by $\boldsymbol{t} \boldsymbol{\prime}$ in Ewe and $\boldsymbol{t} \mathbf{s} \grave{\varepsilon}$ (or $\boldsymbol{l} \boldsymbol{b}$ ) in Ga.

Finally, in terms of the syntactic category of the constituents of possessor bahuvrihi compounds, we see that all the Ewe examples are noun-adjective $(\mathrm{N}-\mathrm{A})$ structures. On the other hand, Akan and Ga have more diverse possibilities in that a compound can have a N-A, noun-noun $(\mathrm{N}-\mathrm{N})$ or even noun-verb $(\mathrm{N}-\mathrm{V})$ structure.

\subsubsection{Location bahuvrihi compounds}

A location bahuvrihi compound is the type which usually refers to a location in time or space, but there is no element that names the specific location. In a number of cases in Akan (as shown in Table 4) there may be a constituent that names a location. However, the location named by the constituent tends to be completely different from that which is named by the whole compound. 
Table 4: Location bahuvrihi compounds in Akan

\begin{tabular}{|c|c|c|c|c|}
\hline Compound & Constituents & Gloss & Translation & Pattern \\
\hline àfíásé & àfí-àsé & house-under & prison & $\mathrm{N}-\mathrm{N}$ \\
\hline dùáásé & dùá-àsé & tree-under & name of a town & $\mathrm{N}-\mathrm{N}$ \\
\hline m̀mòfráásé & m̀-mòfrá-àsé & PL-child-under & childhood (time) & $\mathrm{N}-\mathrm{N}$ \\
\hline gáès-àsé & gáès-àsé & guys-under & place where guys meet & $\mathrm{N}-\mathrm{N}$ \\
\hline àkómásé & àkóḿ-àsé & ritual.dance-under & location of a ritual dance & $\mathrm{N}-\mathrm{N}$ \\
\hline ḿbóádúá dò & ḿbóádúá-dò & fishing net tree-top & $\begin{array}{l}\text { place for keeping fishing } \\
\text { nets/location of 'mboadua' }\end{array}$ & $\mathrm{N}-\mathrm{N}$ \\
\hline
\end{tabular}

The Akan location bahuvrihi compounds are N-N structures in which the left-

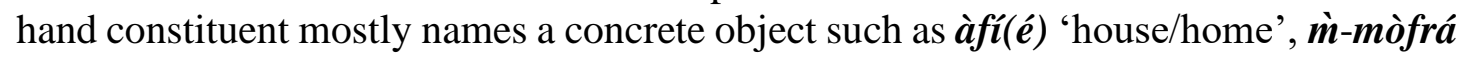
'children', dùá 'tree', etc., and, in one instance, an activity - àkóm 'ritual dance (of the traditional priest)'. The right-hand constituent, on the other hand, is usually a locative/relator noun like àsé 'underside/bottom' and dó 'top' (Osam, Duah and Blay 2011). ${ }^{3}$

The Ewe location bahuvrihi compounds refer to the place where the denotatum of the compound happens or is located (Table 5). The right-hand constituents of the Ewe location bahuvrihi compounds are regarded as postpositions (Agbadah 2017). Hence, they are noun-postposition (N-P) compounds, except the last one which has an $\mathrm{N}-\mathrm{N}$ structure.

Table 5. Location bahuvrihi compounds in Ewe

\begin{tabular}{llllc}
\multicolumn{1}{c}{ Compound } & Element & Element Gloss & Meaning & Pattern \\
\hline àfòdzí & àfò-dzí & leg-upper surface & toilet & N-P \\
kpóxā & kpó-xā & fence/wall-behind & latrine & N-P \\
kpó dzí & kpó-dzí & mound-upper surface & hill top, location of a school & N-P \\
kódzí & kó-dzí & mount-top & hospital & N-P \\
núgódō & nú-gódō & thing-behind & toilet & N-P \\
bèmè & bè-mè & thatch-inside & where thatch is fetched & N-P \\
tòmè & tò-mè & river/stream-inside & place where water is fetched & N-P \\
àhàmè & àhà-mè & liquor/palmwine-inside & place where palm wine is made & N-P \\
kútèfé & kú-tèfé & death-place & funeral & N-N \\
\hline
\end{tabular}

These Ewe compounds are regarded as exocentric because of their apparent contemporary non-transparency/compositionality. There are, however, hints about the motivation for their initial formation. One speaker suggested that kpódzí, for example,

\footnotetext{
${ }^{3}$ The status of the right-hand constituents is the subject of some debate, whether they are nouns or postpositions. In this paper, I work with the position of Osam, Duah and Blay (2011) that they are nouns without necessarily endorsing their position. The details will not necessarily affect the analysis beyond the fact that the output would be either a noun-noun or a noun-postposition compound.
} 
became the name of the location of a school because schools used to be built on hills or elevated grounds. The same understanding underpins kódzí (lit. mount top) which refers to a hospital. Thus, it has to be noted that the Ewe forms cited here have their primary uses as landscape terms which are transparent, before their "secondary" use as the names of institutions and that it is their secondary use as the names of institutions that is at issue, when we refer to their exocentric use. This is consistent with the view that sometimes, whether a compound will be deemed to be exocentric or endocentric is a matter of interpretation (Fabb 1998).

Ga also has locative bahuvrihi compounds, as shown in Table 6, and they are either N-N or N-V compounds.

Table 6. Location bahuvrihi compounds in $\mathrm{Ga}$

\begin{tabular}{lllll}
\hline Compound & Element & Element Gloss & Meaning & Pattern \\
\hline tsèí (à)shì & tsèí-shìshì & tree-under & resting place & $\mathrm{N}-\mathrm{N}$ \\
kpàtáshì & kpàtá-shìshì & hut-under & kitchen & $\mathrm{N}-\mathrm{N}$ \\
gbátsò-nàà & gbátsò-nàà & foretell-room & prophecy room & $\mathrm{N}-\mathrm{N}$ \\
sòlèmòtsòshì & sòlèmòtsò-shìshì & Prayer tree-under & Prayer ground & $\mathrm{N}-\mathrm{N}$ \\
kpá búì & kpá-búñ & stop hole inside & prison & V/N-N \\
\hline
\end{tabular}

The foregoing discussion of bahuvrihi compounds in the three Kwa languages shows the pattern in Table 7. Of the two subtypes of bahuvrihi compounds identified for Akan (possessor and location) Ewe and Ga definitely have the location type. The status of the possessor type is not certain, although one cannot rule them out completely because some speakers accept them. What is not in doubt, however, is that Ewe and Ga speakers prefer corresponding more transparent constructions with the forms tó and

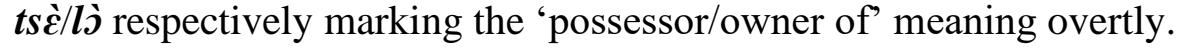

Table 7. Bahuvrihi compounds in Kwa

\begin{tabular}{|c|c|c|}
\hline Language & Possessor & Location \\
\hline Akan & $\checkmark$ & $\checkmark$ \\
\hline Ewe & $? \checkmark$ & $\checkmark$ \\
\hline Ga & $? \vee$ & $\checkmark$ \\
\hline
\end{tabular}

\subsection{Metaphorical compounds}

As described by Bauer (2008a:65), a metaphorical compound is a type of exocentric compound "which names an entity to which the denotatum of the compound is compared." That is, a property of the compositional meaning of the compound is 
compared to a property of the actual referent of the compound. This is done without an overt marker of comparison. Thus, the compounds are to be interpreted metaphorically or by some other figure of speech like synecdoche (Bauer 2016). For example, the referent of Akan àbírékyiré ábódwèsé 'crabgrass' [lit. goat beard] as found in Table 8 is assumed to either look like or be as strong as the beard of a goat - àbirékyiré ábódwèsé.

Table 8: Metaphorical compounds in Akan

\begin{tabular}{lllll}
\hline Compound & Constituents & Gloss & Translation & Pattern \\
\hline àbírékyíré ábódwèsć & àbírékyíré-àbòdwèsé & goat-beard & crabgrass (digitaria) & N-N \\
ànòkóró & ànó-kóró & mouth-one & unity & N-Num \\
hwèǹtéáá & hwéné-téáá & nose-slim & rosemary, a spice & N-A \\
ṁmóá náń & m̀-móá-náń & PL-animal-leg & lost course & N-N \\
ǹtr̀̀bànám & ǹtróbá-nám & egg plant-mean & weakling & N-N \\
òdwáńkókòó & òdwáń-kòkòó & sheep-red & dog (for the Kwahu & N-A \\
& & & people) & \\
\hline
\end{tabular}

The Ewe compounds in Table 9 fit the description of metaphorical compounds. For example, a wrinkle is characterised as kèsé-(à)kàbà 'monkey tribal mark'. In many African cultures, people are identified by their tribal marks which are made mostly on the forehead or the cheeks of the person. Thus, the wrinkle in the face of a person is referred to by comparing it to that which occurs on the forehead of a monkey, identifying it as a monkeys, just as the tribal mark identifies the bearer as a member of the people group that s/he belongs to.

Table 9. Metaphorical compounds in Ewe

\begin{tabular}{|c|c|c|c|c|}
\hline Compound & Element & Element Gloss & Meaning & Pattern \\
\hline \multirow{3}{*}{$\begin{array}{l}\text { kèsé-(à)kàbà } \\
\text { jòlì xèyí } \\
\text { àyótō }\end{array}$} & kèsé-àkàbà & monkey-tribal mark & wrinkle & $\mathrm{N}-\mathrm{N}$ \\
\hline & yjlì-xèxí & ghost-umbrella & mushroom & $\mathrm{N}-\mathrm{N}$ \\
\hline & ànj̀-tō & paint or bitumen-ear & dandelion & $\mathrm{N}-\mathrm{N}$ \\
\hline kèsé-kúkú & kèsé-kúkú & monkey-hat & mockery & $\mathrm{N}-\mathrm{N}$ \\
\hline zãnú & zã-nú & night-thing & bribe & $\mathrm{N}-\mathrm{N}$ \\
\hline gbèvú & gbè-àvú & bush-dog & ruffian & $\mathrm{N}-\mathrm{N}$ \\
\hline zã̀vú & zã̀-vú & night-car & deceit & $\mathrm{N}-\mathrm{N}$ \\
\hline j̀kúgã & j̀kú-gã & eye-big & greed & $\mathrm{N}-\mathrm{A}$ \\
\hline túkpúí & tú-kpuie & gun-short & juju/charm & $\mathrm{N}-\mathrm{A}$ \\
\hline
\end{tabular}

Ga exocentric compounds that are metaphorical in nature, as shown in Table 10, are very much like the Akan equivalents. For example, a location that is difficult to access is referred to by comparing it with the anus of a tortoise which, given the 
tendency of the tortoise to hide securely in its shell, is almost impossible to access without extreme inducement or violence, including killing the tortoise.

Table 10. Metaphorical compounds in Ga

\begin{tabular}{lllll}
\hline \multicolumn{1}{c}{ Compound } & Element & Element Gloss & Meaning & Pattern \\
\hline tòó líí & tòólílćí & goat-tongue & dandelion & $\mathrm{N}-\mathrm{N}$ \\
tòò gbéí & tòò-gbéí & goat-testicles & doughnut & $\mathrm{N}-\mathrm{N}$ \\
bàâ drò & bàâ-drò & crocodile-bile & Something that is very bitter & $\mathrm{N}-\mathrm{N}$ \\
hálá dúnà & hálá-dúnà & tortoise-anus & a place that is difficult to access & $\mathrm{N}-\mathrm{N}$ \\
\hline
\end{tabular}

We observe from the discussion in this section that all the three Kwa languages have metaphorical compounds whose referent vary widely, including, human beings, plants, locations and abstract concepts. In terms of the syntactic categories of the constituents, we see that Ga metaphorical compounds are all N-N combinations. Ewe and Akan, on the other hand, are a bit more diverse in the syntactic categories of the constituents, with two different combinations of word classes for Ewe (N-N \& N-A) and three combinations for Akan (N-N, N-A \& N-Num). Here numerals are treated as constituting a separate word class.

\subsection{Exocentric synthetic compounds}

The exocentric synthetic compound was originally characterised as the type in which a verb and its object (internal argument) form a compound that refers to the subject or external argument of the verb (Bauer 2008a). The examples that Bauer provides are all agentive nominals. However, Appah (2016b) distinguishes three different subtypes of exocentric synthetic compounds that may be grouped into two action/event and participants (agentive and patient). I show how they manifest in the three Kwa languages below.

\subsubsection{Action exocentric synthetic compounds}

This is the type of exocentric synthetic compounds that refers to an action/event, manner of carrying out the action, the fact of the action occurring, the result of the action, etc. (Appah 2017b, Koptjevskaja-Tamm 2005, 2006). Akan examples from the Fante dialect are in Table 11. In these compounds, the internal argument of the verb assumes a generic non-referential function and the meaning of the whole compound can usually be worked out from the meanings of the constituent verb and its argument (Appah 2016b, 2017b, Appah, Duah and Kambon 2017). However, they are exocentric because they fail the hyponymy test in that the whole compound is not a subtype of 
either the nominal constituent or the potential head/selecting element which is a verb (cf. Bisetto and Scalise 2007) because the compound as a whole is a noun (cf. Bauer 2008a, 2010).

Table 11: Action nominal exocentric synthetic compounds in Akan

\begin{tabular}{lllll}
\hline Compound & Constituents & Gloss & Translation & Pattern \\
\hline àdzè-sć' '́ & àdzé-sc̀è & thing-to destroy & wastefulness & $\mathrm{N}-\mathrm{V}$ \\
èdzìbàǹndzí & èdzìbáń-dzí & food-to eat & (act of) eating & $\mathrm{N}-\mathrm{V}$ \\
àdzè-t’́ & àdzé-tó & thing-to buy & (act of) buying & $\mathrm{N}-\mathrm{V}$ \\
àdzè-tóń & àdzé-tóń & thing-to sell & (act of) selling & $\mathrm{N}-\mathrm{V}$ \\
èdzìbàǹnòá & èdzìbáń-nòà & food-to cook & (act of) cooking & $\mathrm{N}-\mathrm{V}$ \\
bàkà-nú & bàká-nú & lagoon-to stir & fishing in a lagoon & $\mathrm{N}-\mathrm{V}$ \\
àdzè-sùá & àdzé-sùà & thing-to learn & education, learning & $\mathrm{N}-\mathrm{V}$ \\
àsè-kyèré & àsè-kyèré & meaning-to show & interpretation/explanation & $\mathrm{N}-\mathrm{V}$ \\
\hline
\end{tabular}

Here, contra previous analysis, I assume that the right-hand constituent of these $\mathrm{N}-\mathrm{V}$ compound is not nominalized (cf. Appah 2017b). Previous analysts (Anderson 2013, Anyidoho 1990) assumed the prior nominalization of the right-hand constituents of such compounds, making them endocentric, based mainly on a pattern of downstep observed on the first syllable of the right constituents of some compounds of this type. This is exemplified in (3), where the high tone on the second constituent of the compound is downstepped or lower in pitch than the high tone on the preceding syllable.

$$
\begin{aligned}
& \text { òsé-'bj 'jubilation' from òsé 'outry' bj 'make' } \\
& \text { àhá-'ý 'hunting' " c̀há 'hunting,5 yélyó 'do' } \\
& \text { ̀̀tém-'pé 'haste' " ìtém 'quickly' pé 'want' }
\end{aligned}
$$

(Dolphyne 1988:123)

Proponents of the prior nominalization view argue that it is the floating low tone of a deleted nominal(izing) prefix that exerts a lowering effect on the following high tone. For those compounds that do not show the downstep, like those in Table 11, it is observed rightly that there is no downstep because there is no high tone on the final

\footnotetext{
${ }^{4}$ A superscript $(!)$ before a tone-bearing unit (TBU) indicates that the high tone on the TBU is downstepped.

${ }^{5}$ The word غ̀ná should be glossed 'forest' not 'hunting', as Dolphyne does, because it designates the location where the activity of hunting takes place, rather than the hunting itself (cf. Christaller 1933: $164,169)$.
} 
syllable of their first constituents. This way, the phonological condition for the downstep is not met. However, Appah, Duah and Kambon (2017) argue that there are many more places where the structural condition for the application of the purported nominalization-signalling downstep is met and yet the downstep does not apply. Thus, it is suggested that evidence for the prior nominalization of the right-hand constituent is at best weak. Therefore, following Appah (2015), it is argued that the compounds are exocentric and that the nominal syntactic category has to be seen as a holistic property of Akan compounds in general. This no-prior-nominalization view is the point of departure in the present paper.

My consultants did not provide such compounds for Ewe and Ga. I suppose that this is because, in these languages, the right-hand constituents of such compounds are assumed to be nominalized, making them endocentric, much like previous accounts of the Akan N-V compounds. For example, the Ewe compounds in Table 12, which have the same semantic import as the Akan $\mathrm{N}-\mathrm{V}$ compounds in Table 11, are analysed as noun-noun action nominal constructs in which the right-hand constituents are nominalized through reduplication (Ameka 1999, Ofori 2002).

Table 12: Action nominal in Ewe

\begin{tabular}{lllll}
\hline Compound & Constituents & Gloss & Translation & Pattern \\
\hline nú-dūdū & dù-nú & thing-eat & eating & N-N \\
kpó-títí & tí-kpó & jump-? & jumping & N-N \\
tsì-kùkú & kù-tsì & fetch-water & testing & N-N \\
hà-dzìdzì & dzì-hà & sing-song & singing & $\mathrm{N}-\mathrm{N}$ \\
vù- $f$ ófō & fò-vù & beat-drum & drumming & N-N \\
dzì-dódó & dó-dzì & plant-heart & endurance & N-N \\
kókó- $f o ́ f \bar{o}$ & fò-kókó & cook-porridge & pleading & N-N \\
\hline
\end{tabular}

In the literature on action nominalization, this type of Ewe compound falls under the valency-lowering type in which a transitive verb and its internal argument form a composite whose only argument will be the external argument of the verb (Koptjevskaja-Tamm 1993:184-85). Here, it is assumed that the verb is first nominalized and the nominalized verb inherits the internal argument of the underlying verb, as argued for in the literature on derived nominals (see Booij 1988, Hoekstra 1986, Lieber 1989, 1992).

\subsubsection{Agent(ive) exocentric synthetic compounds}

The agentive exocentric synthetic compound refers to the entity that performs the action designated by the compositional meaning of the compound, although there 
are no forms that carry the agent(ive) meaning. Akan examples of agentive exocentric synthetic compounds are in Table 13.

Table 13: Agentive exocentric synthetic compounds in Akan (Appah 2017b)

\begin{tabular}{llllc}
\hline Compound & Constituents & Gloss & Translation & Pattern \\
\hline kóṅsúó & kó-ńsúó & fetch-water & one who fetches water & V-N \\
kóànyíná & kó-ànyíná & fetch-firewood & one who fetches firewood & V-N \\
bóótiré & bó-ètíré & plait-hire & one who plaits hair/hair dresser & V-N \\
díàwúó & dí-àwù & cause-death & murderer (this is a surname) & V-N \\
kúṁkóm & kúḿ-kóm & kill-hunger & hunger killer (early-maturing maize variety) & V-N \\
díàbóró & dí-àbóró & cause-wickedness & a malevolent person & V-N \\
\hline
\end{tabular}

In these Akan compounds, the entity that performs the action designated by the compound is not explicitly mentioned in the compound itself. For instance, the literal meaning of the first example in Table 13 is an action of fetching water, but the compound refers to the entity that carries out the action of fetching the water. See an extended discussion of these compounds in Appah (2016a, 2019).

Ewe also has agentive exocentric synthetic compounds which have the same verb-object constituent order as the corresponding Akan compounds. However, as shown in Table 14, unlike Akan, the verb-object structure is reduplicated to form the word (Ofori 2002:176). Thus, we may call them reduplicative compounds.

Table 14. Agentive exocentric synthetic compounds in Ewe

\begin{tabular}{llll}
\hline \multicolumn{1}{c}{ Compound } & Element Gloss & Reduplicated form & Meaning \\
\hline dù-àtí & eat-wood & dùàtí dùàtí & wood beetle \\
lò-àtí & make hollow wood & lòtí lòtí & wood pecker \\
dzà-hà & buy-drink & dzè àhà & one who buys drinks (Ofori 2002:179) \\
\hline
\end{tabular}

Because we did not get any examples from the Ga consultants, we may say, for now, that Ga does not have agentive exocentric synthetic compounds. This might be because, just like bahuvrihi compounds, Ga speakers prefer transparent structures in which all meaning components are formally anchored. Therefore, the relevant

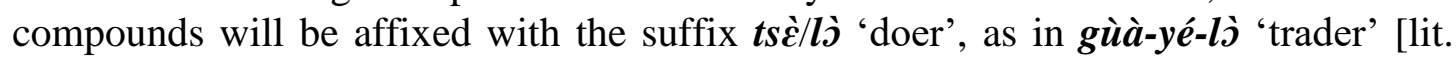
market-eat-person], rather than just gùà-yé which would be expected, if Ga were to follow the same pattern as Akan. 


\subsubsection{Patient exocentric synthetic compounds}

The patient type of exocentric synthetic compound refers to the entity that undergoes or suffers the effect of the compositional meaning of the compound. However, there is no overt unit in the compound that carries the meaning, patient or sufferer. This is exemplified by the Akan compound díamiá in Table 15 which refers to the entity that suffers a misfortune rather than the one that causes the misfortune. This example can be compared to the corresponding agentive compound díâbóró 'malevolent person' in Table 13, whose referent causes the effect of the literal meaning of the compound.

Table 15: Patient exocentric synthetic compounds in Akan

\begin{tabular}{llllc}
\hline Compound & Constituents & Gloss & Translation & Pattern \\
\hline díàmìa & dí-àmìa & $\begin{array}{l}\text { suffer-state of being } \\
\text { helmed in }\end{array}$ & $\begin{array}{l}\text { one who has suffered a } \\
\text { misfortune }\end{array}$ & V-N \\
& & & \\
\hline
\end{tabular}

The Ewe and Ga consultants did not provide any examples of patient exocentric synthetic compounds and the reason will not be different from the reason given for the absence of agent(ive) exocentric synthetic compounds in these two languages.

Thus, the picture that emerges from the survey of exocentric synthetic compounds in the three Kwa languages is as presented in Table 16. Akan has three subtypes - action, agentive and patient. Ewe has the agentive type whilst Ga has none at all.

Table 16. Exocentric Synthetic compounds in Kwa

\begin{tabular}{|c|c|c|c|}
\hline Language & Action & Agentive & Patient \\
\hline Akan & $\checkmark$ & $\checkmark$ & $\checkmark$ \\
\hline Ewe & - & $\checkmark$ & - \\
\hline Ga & - & - & - \\
\hline
\end{tabular}

\subsection{Transpositional exocentric compounds}

In a transpositional exocentric compound, it is only the word class of the compound that is not overt. This means that the compound functions as a member of a word class that is different from the word class of its constituents (Bauer 2008a).

Akan examples of transpositional exocentric compounds are those in Table 17 in which the composition of two verbs yields a noun (Appah 2017a, b). The two verbs 
in each such transpositional exocentric compound may also be found occurring together as verbs in a serial verb construction but the compound that is formed may not be used as a verb and cannot admit internal inflectional marking, such as tense and polarity, because it is a noun (Appah 2017a). ${ }^{6}$

Table 17. Transpositional exocentric compound in Akan (Appah 2017a)

\begin{tabular}{lllll}
\hline Compound & Form & Gloss & Translation & Pattern \\
\hline tútá & tú-tá & uproot-fart & a weed & V-V \\
prèhwé & prè-hwé & tap-see & gossiping & V-V \\
gyédzí & gyé-dzí & receive-eat & faith/belief & V-V \\
kámá & ká-má & say-give & intercession & V-V \\
dzímá & dzí-má & eat-give & intercession & V-V \\
sóhwé & só-hwé & try-see & tribulation/temptation & V-V \\
sòmákó & sòmà-kó & send-go & faithfulness in going on errands & V-V \\
\hline
\end{tabular}

Ewe also seems to have transpositional exocentric compounds that are formed from the composition of two verbs to form a noun. The Ewe examples in Table 18 are drawn in part from Ofori (2002), while the rest were elicited from the consultants. Some of the constituents are reduplicated before they form a compound with the other constituent. We can tell the meaning of these compounds, as noted above. What is missing is the syntactic category that cannot be accounted for in the constituents unless we assume the prior-nominalization of at least one of the constituents.

Table 18. Transpositional exocentric compounds in Ewe

\begin{tabular}{llllll}
\hline Compound & Elements & Element Gloss & Meaning & Pattern & Source \\
\hline dàflè & dà-flè & cook-buy & cooked food for sale & V-V & Ofori \\
xòsè & xò-sè & get-hear & faith/belief & V-V & $(2002: 179)$ \\
xóvé & xò-vé & take-come/bring & destiny & V-V & \\
gbòxí & gbò-xí & breath-block & asthma & V-V & \\
tsódù & tsó-dù & take-eat & benefit & V-V & \\
xòvé & xò-vé & take-come & destiny & V-V & \\
zòzòvá & zò vá & walk-come & coming by walking & V-V & Ofori (2002:176) \\
dj̀dókpó & dó-kpó & taste-see & tasting & V-V & \\
dòdókpó & dó kpó & wear-see & examination & V-V & \\
\hline
\end{tabular}

\footnotetext{
${ }^{6}$ It is noted elsewhere (Appah 2015, 2017a) that these compounds provide the strongest evidence for the view that the syntactic category of the Akan compound is a holistic constructional property that does not depend on the syntactic category of the constituents.
} 


\subsection{Summary}

In this section, I have presented the various types of exocentric compounds that are found in the three Kwa languages, starting from what had been found in Akan (Appah 2016a, b, c, 2017a, b, Appah, Duah and Kambon 2017). It has been shown that all the four types identified in Akan are also attested in Ewe to various degrees, except the action and patient exocentric synthetic compounds. Ga generally seems to have limited number of exocentric compounds with only the bahuvrihi and metaphorical types found in the language.

The pattern that emerges from the survey is summed up in Table 19. The question mark (?) before the tick $(\checkmark)$, as in (? $\checkmark)$, is meant to capture the fact that the status of the relevant compound (the possessor bahuvrihi compounds) in these languages is not settled.

Table 19. Summary of the types of exocentric compound in Akan, Ewe and Ga

\begin{tabular}{|c|c|c|c|c|c|c|c|}
\hline Types & \multicolumn{2}{|c|}{ Bahuvrihi } & $\begin{array}{c}\text { Metapho } \\
\text { rical }\end{array}$ & \multicolumn{2}{c|}{ Exocentric synthetic } & Transpositional \\
\hline \multirow{2}{*}{ Language } & Possessor & Location & & Action & Participant & \\
\cline { 5 - 7 } Akan & $\checkmark$ & $\checkmark$ & $\checkmark$ & $\checkmark$ & $\checkmark$ & $\checkmark$ & $\checkmark$ \\
\hline Ewe & $? \checkmark$ & $\checkmark$ & $\checkmark$ & - & $\checkmark$ & - & $\checkmark$ \\
\hline $\mathrm{Ga}$ & $? \checkmark$ & $\checkmark$ & $\checkmark$ & - & - & - & - \\
\hline
\end{tabular}

\section{Conclusion}

The study of exocentric compounds in this paper has revealed some interesting patterns regarding the types and their spread in the three Kwa languages as well as the syntactic categories of the constituents. We have seen that of the five main types posited in Bauer (2008a, 2010), four occur in the three Kwa languages. These are bahuvrihi, metaphorical, exocentric synthetic and transpositional exocentric compounds. All three languages have bahuvrihi compounds and their two subtypes - possessor and location - except that some speakers of Ewe and Ga observed that they would use constructions with forms overtly marking the possessor meaning. Also, all the languages have metaphorical compounds. Only Akan and Ewe have exocentric synthetic and transpositional exocentric compounds. Ewe has the agentive, but not the action and patient subtypes of exocentric synthetic compounds.

Giving the foregoing, we can recast the typology of exocentric compounds, based on Bauer's work and the suggested subtypes, as shown on the taxonomic tree below. 


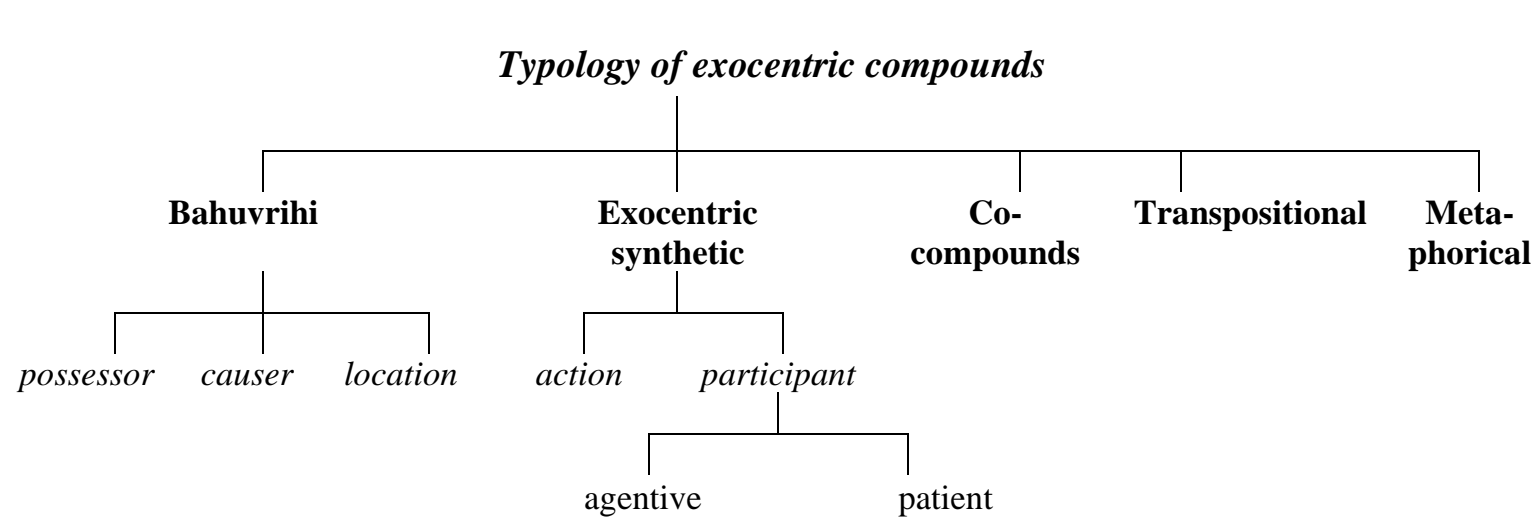

One issue that comes out strongly from the survey in this paper is the need for conversation about the best way to gather data on exocentric compounds crosslinguistically. Also, there has to be further refinement of the classification criteria and types of exocentric compounds. Putting the Ewe data in the various classes proved particularly challenging. The data therefore requires further critical study hopefully by someone with native-speaker intuitions about the data. As Ralli (2019:284) observes, "well-based studies are those for which the authors are either native speakers of the language where the investigated data come from, or have extensive work on them."

\section{References}

Agbadah, A. K. 2017. "Compounding in Ewe." MPhil MPhil Thesis, Department of Linguistics University of Ghana, Accra.

Ameka, F. 1991. "Ewe: Its Grammatical and Illocutionary Devices." Unpublished Ph. D. dissertation, ANU, Canberra.

Ameka, F. K. 1999. "The Typology and Semantics of Complex Nominal Duplication in Ewe." Anthropological linguistics 41(1):75-106.

Anderson, J. C. 2013. "Verb-Internal Compound Formation in Akan." Journal of West African Languages XL(1):89-104.

Andreou, M. 2014. "Headedness in Word Formation and Lexical Semantics: Evidence from Italiot and Cypriot." PhD Dissertation, Universityof Patras.

Andreou, M. and A. Ralli. 2015. "Form and Meaning of Bahuvrihi Compounds: Evidence from Modern Greek and Its Dialects." Pp. 163-85 in Semantics of Complex Words, edited by L. Bauer, L. Körtvélyessy and P. Štekauer. Dordrecht: Springer. 
Anyidoho, A. 1990. "On Tone in Akan Compound Nouns." Paper presented at the the 19th West African Languages Congress, April 2-6, 1990, University of Ghana, Legon.

Appah, C. K. I. 2013. "Construction Morphology: Issues in Akan Complex Nominal Morphology." PhD dissertation, Department of Linguistics and English Language, Lancaster University, Lancaster, UK.

Appah, C. K. I. 2015. "On the Syntactic Category of Akan Compounds: A ProductOriented Perspective." Acta Linguistica Hungarica 62(4):361-94. doi: 10.1556/064.2015.62.4.1.

Appah, C. K. I. 2016a. "Akan Verb-Noun Compounds." Italian Journal of Linguistics 28(2):3-24

Appah, C. K. I. 2016b. "A Short Note on the Typology of Exocentric Compounds." SKASE Journal of Theoretical Linguistics 13(1):107-13.

Appah, C. K. I. 2016c. "Noun-Adjective Compounds in Akan." Lingue e linguaggio XV(2):259-84. doi: 10.1418/84978.

Appah, C. K. I. 2017a. "On Holistic Properties of Morphological Constructions: The Case of Akan Verb-Verb Nominal Compounds." Acta linguistica hafniensia 49(1):12-36. doi: 10.1080/03740463.2016.1242331.

Appah, C. K. I. 2017b. "Exocentric Compounds in Akan." Word Structure 10(2):13972. doi: 10.3366/word.2017.0106.

Appah, C. K. I., R. A. Duah and O. B. Kambon. 2017. "Akan Noun-Verb Compounds: The Exocentric Synthetic View." Language Sciences 64:1-15. doi: 10.1016/j.langsci.2017.05.001.

Appah, C. K. I. 2019. "Analytical Issues in the Study of Verb-Noun Compounds: How Does Akan Fit In?". Acta Linguistica Academica 66(1):1-29. doi: 10.1556/2062.2019.66.1.1.

Bauer, L. 2008a. "Exocentric Compounds." Morphology 18:51-74. doi: 10.1007/s11525-008-9122-5.

Bauer, L. 2008b. "Les Composés Exocentriques De L'anglais." Pp. 35-47 in La Composition Dans Une Perspective Typologique, edited by D. Amiot. Arras: Artois Presses Université.

Bauer, L. 2010. "The Typology of Exocentric Compounds." Pp. 167-75 in CrossDisciplinary Issues in Compounding, edited by S. Scalise and I. Vogel. Amsterdam/Philadelphia: John Benjamins Publishing Company.

Bauer, L. 2016. "Re-Evaluating Exocentricity in Word-Formation." Pp. 461-78 in Morphological Metatheory, edited by D. Siddiqi and H. Harley. Amsterdam: John Benjamins Publishing Company.

Bauer, L. 2017. Compounds and Compounding. Cambridge: Cambridge University Press. 
Benczes, R. 2005a. "Metaphor- and Metonymy-Based Compounds in English: A Cognitive Linguistic Approach." Acta Linguistica Hungarica 52(2):173-98. doi: 10.1556/ALing.52.2005.2-3.3.

Benczes, R. 2005b. "Creative Noun-Noun Compounds." Annual Review of Cognitive Linguistics 3(1):250-68.

Benczes, R. 2006. Creative Compounding in English: The Semantics of Metaphorical and Metonymical Noun-Noun Combinations. Amsterdam: John Benjamins Publishing Company.

Benczes, R. 2015. "Are Exocentric Compounds Really Exocentric?". SKASE Journal for Theoretical Linguistics 12(3):54-73.

Bisetto, A. and S. Scalise. 2005. "The Classification of Compounds." Lingue $e$ linguaggio (2):319-0.

Bisetto, A. and S. Scalise. 2007. "Selection Is a Head Property." Acta Linguistica Hungarica 54(4):361-80.

Bloomfield, L. 1933. Language. New York: Holt, Rinehart and Winston.

Booij, G. E. 1988. "The Relation between Inheritance and Argument Linking: Deverbal Nouns in Dutch." Pp. 57-74. in Morphology and Modularity. In Honour of Henk Schultink, edited by M. Everaert, A. Evers, H. R. and M. Trommelen. Dordrecht: Foris.

Booij, G. E. 2002. The Morphology of Dutch. Oxford: Oxford University Press.

Booij, G. E. 2007. The Grammar of Words: An Introduction to Linguistic Morphology. Oxford: Oxford University Press.

Christaller, J. G. 1933. Dictionary of the Asante and Fante Language Called Tshi (Chwee, Twi): With a Grammatical Introduction and Appendices on the Geography of the Gold Coast and Other Subjects. Basel: Basel Evangelical Missionary Society.

Di Sciullo, A.-M. and E. S. Williams. 1987. On the Definition of Word, Vol. 14. Cambridge, MA: MIT Press.

Dixon, R. M. W. 2004. "Adjective Classes in Typological Perspective." Pp. 1-49 in Adjective Classes: A Cross-Linguistic Typology, edited by R. M. W. Dixon and A. Y. Aikhenvald. Oxford: Oxford University Press.

Dolphyne, F. A. 1988. The Akan (Twi-Fante) Language: Its Sound Systems and Tonal Structure. Accra: Ghana Universities Press.

Dressler, W. U. 2006. "Compound Types." Pp. 23-44 in The Representation and Processing of Compound Words, edited by G. Libben and G. Jarema. Oxford: Oxford University Press.

Fabb, N. 1998. "Compounding." Pp. 66-83 in The Handbook of Morphology, edited by A. Spencer and A. M. Zwicky. Oxford: Basil Blackwell. 
Guevara, E. R. and S. Scalise. 2009. "Searching for Universals in Compounding." Pp. 101-28 in Universals of Language Today, edited by S. Scalise and A. Bisetto. Dordrecht: Springer Science + Business Media B.V.

Hoekstra, T. 1986. "Deverbalization and Inheritance." Linguistics 24(3):549-84.

Katamba, F. X. and J. T. Stonham. 2006. Morphology. Basingstoke: Palgrave Macmillan.

Koptjevskaja-Tamm, M. 1993. Nominalizations. London/New York: Routledge.

Koptjevskaja-Tamm, M. 2005. "Action Nominal Constructions." Pp. 254-58 in The World Atlas of Language Structures, edited by M. Haspelmath, M. S. Dryer, D. Gil and B. Comrie. Oxford: Oxford University Press.

Koptjevskaja-Tamm, M. 2006. "Nominalization." Pp. 652-59 in Encyclopedia of Language and Linguistics, edited by K. Brown. Oxford: Elsevier.

Lieber, R. 1989. "On Percolation." Yearbook of Morphology 2:95-138.

Lieber, R. 1992. Deconstructing Morphology: Word Formation in Syntactic Theory. Chicago, Illinois: University of Chicago Press.

Marchand, H. 1969. The Categories and Types of Present-Day English WordFormation: A Synchronic-Diachronic Approach. Munich: C. H. Beck Verlagsbuchhandlung.

Ofori, K. A. G. 2002. "Nominalisation in Ewe." Pp. 173-94 in New Directions in Ghanaian Linguistics, edited by F. K. Ameka and E. K. Osam. Accra: Black Mask.

Osam, E. K. 1999. "Adjectives in Akan." Afrika und Übersee 82(2):189-211.

Osam, E. K., R. A. Duah and A. M. Blay. 2011. "The So-Called Postpositions in Akan: A Reconsideration." Journal of West African Languages XXXVIII(2):107-18.

Otoo, S. K. 1946. Apoks Ho Nyimdzee. Cape Coast: Methodist Book Depot.

Plag, I. 2003. Word-Formation in English. Cambridge: Cambridge University Press.

Ralli, A. and M. Andreou. 2012. "Revisiting Exocentricity in Compounding: Evidence from Greek and Cypriot." Pp. 65-81 in Current Issues in Morphological Theory:(Ir) Regularity, Analogy and Frequency. Selected Papers from the 14th International Morphology Meeting, Budapest, 13-16 May 2010, edited by F. Kiefer, M. Ladányi and P. Siptar. Amsterdam/Philedelphia: John Benjamins.

Ralli, A. 2013. Compounding in Modern Greek. Dordrecht: Springer.

Ralli, A. 2019. "Book Review: Laurie Bauer, Compounds and Compounding, 2017. Cambridge: Cambridge

University Press, Pp. 208." Folia Linguistica 53(1):277-86.

Scalise, S. 1988. "The Notion of "Head'in Morphology." Yearbook of Morphology 1:229-46.

Scalise, S. and E. R. Guevara. 2006. "Exocentric Compounding in a Typological Framework." Lingue e linguaggio 2:185-206. 
Scalise, S. and A. Bisetto. 2009. "The Classification of Compounds." Pp. 34-53 in Oxford Handbook of Compounding, edited by R. Lieber and P. Štekauer. London: Oxford University Press.

Scalise, S. and A. Fábregas. 2010. "The Head in Compounding." Pp. 109-25 in CrossDisciplinary Issues in Compounding, Current Issues in Linguistic Theory, edited by S. Scalise and I. Vogel. Amsterdam/Philadelphia: John Benjamins Publishing Company.

Selkirk, E. O. 1982. The Syntax of Words. Cambridge, MA: MIT Press.

Wälchli, B. 2005. Co-Compounds and Natural Coordination. Oxford: Oxford University Press. 